\title{
Biodegradable Polymers and Stem Cells for Bioprinting
}

\author{
Meijuan Lei ${ }^{1}$ and Xiaohong Wang ${ }^{1,2, *}$ \\ 1 Center of Organ Manufacturing, Department of Mechanical Engineering, Tsinghua University, \\ Beijing 100084,China; lmj15@mails.tsinghua.edu.cn \\ 2 Center of 3D printing \& Organ Manufacturing, Department of Tissue Engineering, \\ China Medical University (CMU), Shenyang 110122, China \\ * Correspondence: wangxiaohong@tsinghua.edu.cn or wangxiaohong709@163.com; Tel.: +86-10-6277-3202
}

Academic Editors: Chee Kai Chua, Wai Yee Yeong and Jia An

Received: 16 March 2016; Accepted: 13 April 2016; Published: 29 April 2016

\begin{abstract}
It is imperative to develop organ manufacturing technologies based on the high organ failure mortality and serious donor shortage problems. As an emerging and promising technology, bioprinting has attracted more and more attention with its super precision, easy reproduction, fast manipulation and advantages in many hot research areas, such as tissue engineering, organ manufacturing, and drug screening. Basically, bioprinting technology consists of inkjet bioprinting, laser-based bioprinting and extrusion-based bioprinting techniques. Biodegradable polymers and stem cells are common printing inks. In the printed constructs, biodegradable polymers are usually used as support scaffolds, while stem cells can be engaged to differentiate into different cell/tissue types. The integration of biodegradable polymers and stem cells with the bioprinting techniques has provided huge opportunities for modern science and technologies, including tissue repair, organ transplantation and energy metabolism.
\end{abstract}

Keywords: bioprinting; organ manufacturing; stem cells; gelatin based hydrogels; tissue engineering

\section{Introduction}

On the basis of statistical data, there were 25.7 million adults and 75,000 children suffering from cancer of stomach, liver, breast, lung, and so on during 1995-2009 [1]. There were 117,040 patients that needed organ transplantation, but only 28,053 suitable organs available in the USA in 2013 [2]. Besides huge economic costs and immunological rejections of allografts, organ shortage has become a great restriction in organ transplantation. For the shortcomings and limitations of the surgical transplantation, scientists have tried various new methods to increase man's life span. These new methods include biomaterial induction, cell therapy, tissue engineering and organ manufacturing approaches [3-6].

More and more evidence has shown that stem cells are the building blocks or backbones for regenerative medicine with their unique functions and advantages of self-renewal, high proliferation, and multiple-directional differentiation abilities [7,8]. The combination of biodegradable polymers with multinozzle 3D bioprinting technologies (i.e., cell assembling techniques) gives the hope to deposit various cells in place to mimic normal biological conditions in vitro and in vivo [9-16].

Recently, complex tissue constructs, such as vascularized liver, adipose, bone, cartilage and muscle tissues, have been fabricated by an integrated tissue-organ printer (ITOP) $[17,18]$. Bioprinting technology has been regarded as the most effective tool for regenerative medicine including tissue engineering and organ manufacturing. Some scientists have considered bioprinting technology as the conjunction of 3D printing and organ manufacturing techniques [19-22]. 
The main characteristic of bioprinting technology is printing cells and extracellular matrices (ECMs) layer by layer to form 3D tissue/organ-like constructs. Cells in bioprinting can be adult cells or stem cells extracted from the patient who requires organ transplantation, which solves the rejection problems that arise from the recipient's immune system. Excelling at tissue engineering, bioprinting can create customized structures with the computer-aided models (CAD) quickly, and print cells, cytokines, or ECMs automatically and precisely. Hence, this technology has been regarded as a forward-looking method to assemble cells and biomaterials rapidly and precisely [19-22].

However, organ manufacturing for organ replacement and reconstruction has not yet been completely applied to clinical treatment with reliable bioartificial organs [23,24]. Especially, functional branched vascular system manufacturing remains a technological barrier that needs to be broken through immediately. At present, most of the existing technologies are limited in simple tissue manufacturing and high-throughput drug screening areas [9-16,25]. Furthermore, 3D bioprinting involves in various aspects such as cell types, biomaterials, and growth factors, of which each factor plays a key role in determining the printing results. The selection of biomaterials is of fundamental importance in bioprinting, which contains a selection of adult or stem cells, synthetic or natural polymers, and growth factors.

3D bioprinting approaches include mechanical enhancement, biomimicry, autonomous self-assembly and mini-tissue formation stages. It brings hope to humanity of biomimetic structures with specially designed patterns, material composition and degradation kinetics, controllable mechanical properties and biological effects. Most importantly, it is possible to obtain complex tissue/organ structures with physical and chemical properties similar to their counterparts with the combination of various factors for tissue and organ regeneration [9-16]. Thus, there are four basic elements in bioprinting technologies: cells, growth factors, biodegradable polymers and bio-printer. Different organ manufacturing technologies differ in these four aspects. Generally, cells, as "bio-inks", are mixed in biodegradable polymer hydrogels before being printed [9-16].

\section{Classification of Bioprinting Techniques}

Based on the working principles, bioprinting technologies have been divided into four classes: inkjet bioprinting, extrusion bioprinting, laser-assisted bioprinting, and ultrasonic bioprinting (Figure 1) [9-16]. Among them, the former three are commonly employed in modern tissue engineering and organ manufacturing areas. In detail, inkjet bioprinting technology is based on simple home printing techniques. Cells and biomaterials such as hydrogels are printed separately layer by layer to form an object using thermal or acoustic methods [26]. Tissues/Organs can be gradually matured when the cells communicate and connect to each other after printing (Figure 1A). During thermal inkjet printing, heat is generated at the printer head and the cells and biomaterials are forced out of the nozzle through pressure pulses. The system temperature can rise $4-10{ }^{\circ} \mathrm{C}$ with no obvious detrimental effect on cell viability $[27,28]$.

In laser-assisted bioprinting or laser bioprinting, a bubble between a solution and a piece of glass is usually created through a vapor pressure (i.e., laser pulse). This pressure shoots a small drop of the solution, including cells, towards the collector substrate. Drop by drop, a tissue-like structure can be produced through the repeated processes. Laser bioprinting has the advantage of high resolution in living cell arrangement. In the meantime, cells undergo thermal and mechanical deformation from the laser during the printing processes. Usually, the damage can be decreased to some degree through incorporating biodegradable polymers in the "bio-inks". Especially, with scaffold biomaterials employed, elegant 3D structures can easily be printed [29,30]. Laser bioprinting can also be employed for multiple cell printing using different cell types in the substrate, which is a vital element for tissue engineering and organ manufacturing (Figure 1F).

Extrusion-based bioprinting is obviously based on the extrusion principle. Fluids, released by a pressure-assisted system, are extruded automatically via a three-axis robotic system to an intended position. There exist multinozzle-based bioprinting systems, which are identified 
as the forward-looking methods to assembly cells and extracellular matrices (ECMs) precisely (Figure 1D) [9-16,31-35].
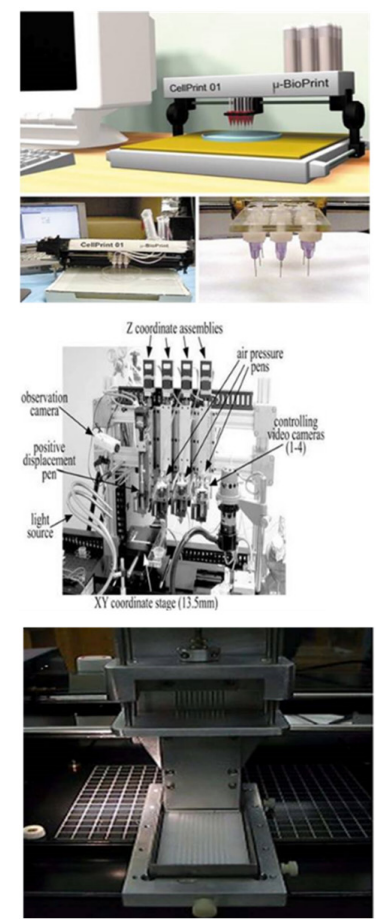

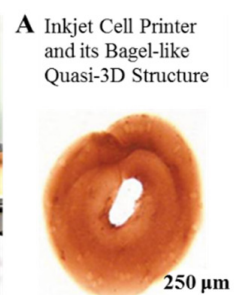

C Direct-Write System
and its Preliminary and its Preli
3D Figures

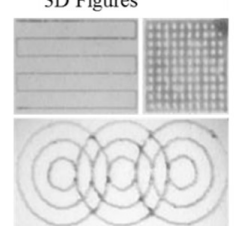

E Bioprinting Tubular Structure with Cellular Cylinders

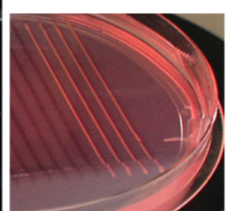

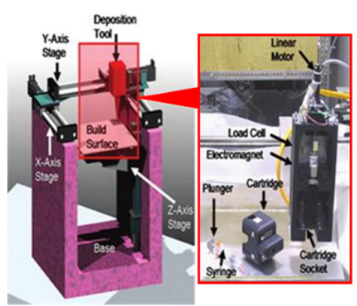

B Robotic Printing Platform and its Crescent Construct
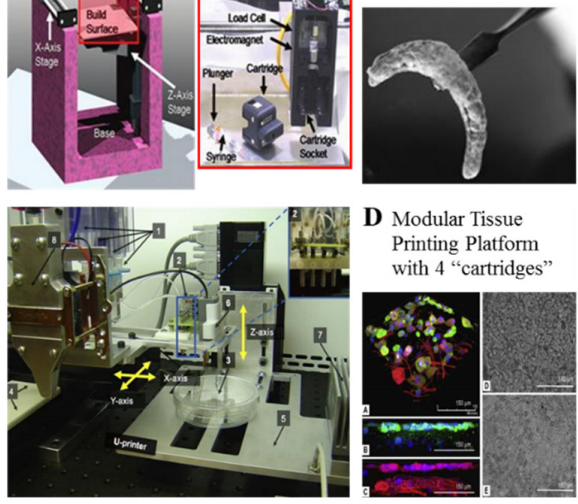

D Modular Tissue Printing Platform with 4 "cartridges"
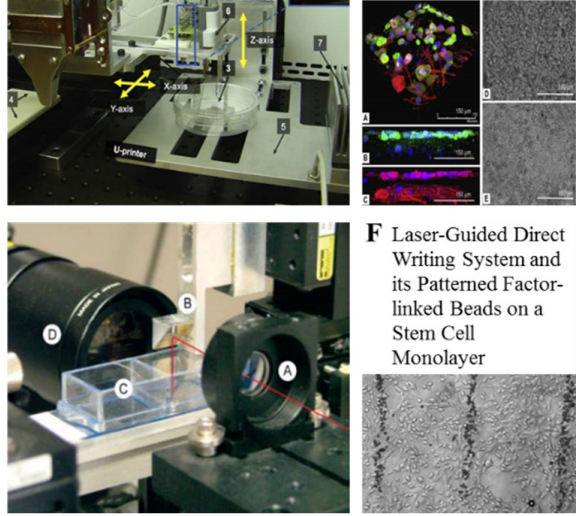

F Laser-Guided Direct Writing System and linked Beads on a Stem Cell Monolayer

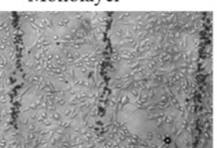

Figure 1. (A) A inkjet cell printer and its bagel-like quasi-3D structure [9]; (B) A robotic printing platform and its crescent construct [9]; (C) A direct-write system and its preliminary 3D figures [9]; (D) A modular tissue printing platform with four "cartridges" to load cell suspensions or hydrogels developed in Brigham and Women's Hospital, Harvard Medical School, Prof. Yoo's group [9]; (E) A bioprinting tubular structure with cellular cylinders developed in University of Missouri, Columbia, USA, Prof. Forgacs' group [9]; (F) A laser-guided direct writing (LGDW) system and its patterned factor-linked beads on a stem cell monolayer with micrometer accuracy $($ Bar $=200 \mu \mathrm{m})$ developed in University of Minnesota, Prof. Odde's group [9].

In general, different bioprinting techniques have dissimilar printing themes and limitations [31-35]. For instance, diversity and affordability are the prominent features of an inkjet bioprinting technique. Different cells and ECMs can be deposited together or separately. When cells are printed in situ (e.g., in patient body), there is no need to have a flat surface or platform to support the outcomes [33]. However, only liquids with low viscosities and low cell numbers can be printed to avoid clogging in the nozzle and to reduce shear stress on the cells. In extrusion bioprinting, the structural integrity of cells and ECMs obviously precedes those in inkjet bioprinting. Multiple cell types with high cell densities can be printed simultaneously using multinozzle printers. It is possible to directly print organs with a branched vascular system because of cells encapsulated in the intrinsic connectible ECMs or scaffold materials [34,35]. Nevertheless, the limited ECM selection and short storage time period of biodegradable polymer hydrogels have an impact on the technical development and practice [9-16,31-36]. In laser-assisted bioprinting, a broad range of biomaterials with various viscosities can be printed without clogging problems. However, the cell printing efficiency needs to be improved [37].

Currently, some achievements have been attained with various cells and biodegradable polymers. For example, adipose-derived stem cells (ADSCs) and mesenchymal stem cells (MSCs) were printed using a laser-assisted bioprinting (LaBP) technique [38,39]. Around five to seven living cells were printed using a laser-induced forward transfer technique with high precision at micron scales [40]. 
Human microvascular endothelial cells together with fibrin were printed using a thermal inkjet printer [41]. An aortic valve-like structure was printed using a microextrusion bioprinter [42]. In parallel, the integration or combination of different cells and biodegradable polymers for extrusion-based 3D bioprinting techniques has been extensively exploited by our group [43-58].

\section{Biodegradable Polymers in Bioprinting}

Biodegradable polymers can be divided into synthetic polymers (such as polyurethane (PU) and poly(lactic-co-glycolic acid) (PLGA)), and natural polymers (such as gelatin and collagen). Both have been widely used in bioprinting techniques with profound influence in cellular activities, histogenese modulation and tissue/organ generation [43-58]. A distinction between the two polymers is that natural polymers are born with bioactivities; on the contrary, synthetic polymers are generally inert. As a result, synthetic polymers are superior to natural polymers in terms of immunogenic responses and mechanical strengths.

The commonly used biodegradable polymers in bioprinting are gelatin, collagen, alginate, chitosan, fibrin, hyaluronic acid and their mixtures, which can be changed from sol to gel states in response to various external stimuli, such as temperature, light, $\mathrm{pH}$, magnetism and electricity [59-61]. As cell loading ECMs or accommodations, these polymers possess the essential characteristics, such as bioactive; biocompatibility; controllable biodegradability (hydrolytically or enzymatically degradable); nontoxic; stable; processibility; storability, and suitable physical (i.e., mechanical, structural, and topological), chemical (i.e., crosslinking) and biological properties [9-16,31-36,43-58,62-65]. Some other biodegradable polymers, such as dextran, starch, resin, agar, matrigel, pluronic F-127, polypeptide-DNA, and poly(acrylic acid), have also been used in bioprinting [66-69]. Besides providing cells with necessary nutrients, water and oxygen, the polymers also play an important role in supporting the printed structures.

Most of the natural biodegradable polymers can be dissolved in cell friendly inorganic solvents to form solutions or hydrogels with good biocompatibility and biodegradability. The solution or hydrogel states of the biodegradable polymers have certain fluidity during bioprinting [43-58]. The mobility of the polymer solutions or hydrogels can be modified in rapid prototyping (RP) devices, and can be manipulated with high resolution and mature accuracy. This is vital important for the biological property retention and tissue/organ recreation during and after cell printing processes [70,71]. These polymers are mainly applied to temporary prosthesis, scaffold formation and drug delivery fields. Several relevant parameters of biodegradable polymers, such as extreme temperatures, organic solvents, and water deficiencies can negatively influence cell viabilities.

Usually, different biodegradable polymers have different printing properties. Certainly, each bioprinting machine has its own taste of biomaterials to match. To some extent, the processibility of the biodegradable polymers determines the availability of biomaterials. Hydrogel, a water-swollen, and cross-linked polymeric network produced by the simple reaction of one or more monomers [9-16,31-36,43-58,62-65,72], plays increasingly role in organ manufacturing as well as bioprinting technologies. In our experience, various hydrogels, typically biodegradable natural or synthetic polymeric solutions, are ideal choices for scaffold biomaterials, which are highly hydrated (water content $\geqslant 30 \%$ by weight) and easily manipulated [9-16,31-36,43-58,62-65,73]. For example, gelatin, with properties such as biocompatible, biodegradable, solubility in water, and a melting point at about $28{ }^{\circ} \mathrm{C}$, is very flexible but strong in hydrogel states, which can easily be manipulated and modified, preventing large molecules diffusion inside randomly [74,75]. As an alternative, collagen is also a fascinating biomaterial, which is rich in mammalian cells and ECM components [76,77]. For its low toxicity and fast-acting property, alginate has been used frequently for cell encapsulation and drug delivery [43-58,78]. To date, the exploration of new biomaterials for tissue and organ printing is still underway [52-58].

Emphasis should be given to those ECMs that play a significant role in cell survival, proliferation, migration and differentiation during and after bioprinting processes, with the principal means of 
mechanical support and biochemical signals $[79,80]$. Many biodegradable polymers combinations, mimicking the properties of ECMs, have been designed for different cell printing [81-83]. In detail, some ECM-like hydrogels have been widely used in the research areas, such as drug delivery, tissue engineering and organ manufacturing, to promote nutrient diffusion, cell migration, angiogenesis, wound healing, and tissue/organ regeneration [5-24,43-58,84].

Normally, the printing temperatures of cells encapsulated in the ECM-like polymer hydrogels should be between $1{ }^{\circ} \mathrm{C}$ and $37^{\circ} \mathrm{C}$, in order to avoid ice nucleation or overheat harms to cells [5-24,43-58,85]. In vivo stabilities, compatibilities and degradation rates of polymer hydrogels should be seriously considered before the 3D constructs can be implanted, particularly for soft tissues or organs, such as the liver, heart, and pancreas. Sometimes, the moisture content and permeability of the polymer hydrogels also need to be considered.

For example, alginate, also named as algin or alginic acid, is an anionicpolysaccharide that has been widely used as an ion-sensitive hydrogel for cell encapsulation in drug delivery and bioprinting [86-88]. A remarkable feature of alginate is its ability to be rapidly crosslinked in a cell-endured condition upon contact with divalent cations, such as calcium, strontium, and barium and zinc ions. However, the crosslinking processes are reversible. When the resulted complexes are cultured in liquid media and the chelated divalent cations are released from the hydrogels, the printed structures cannot be maintained for a long period. To solve this problem, we have further incorporated crosslinkable chitosan or polymerizable fibrinogen in the gelatin based cell-printing matrices [45-58]. Besides being ion-crosslinked, the alginate-based hydrogels can also be photo-crosslinked or enzyme-crosslinked [45-58,88,89]. In addition, to increase the biocompatibilities of alginate, some researchers have modified alginate hydrogels with cell-adhesive peptide, such as RGD, or ECM-like components, such as gelatin or collagen [90].

In our group, we have chosen gelatin based natural biodegradable polymers, such as gelatin/chitosan, gelatin/alginate, gelatin/hyaluronan, gelatin/alginate/chitosan and gelatin/ alginate/fibrinogen as the main component of ECM for various extrusion-based cell-printing techniques [5-24,43-58]. Tailor-made nozzles or thin syringe needles have been employed to print the cell-laden hydrogels. The printing processes have nearly no harm to the encapsulated cells. Glycerol, dextran, dimethyl sulfoxide and other bioactive factors can be incorporated into the gelatin-based hydrogels directly $[43-58,85]$. Gelatin is a denatured, biodegradable polypeptide derived from partial hydrolyzed collagen, which is widely found in human tissues [9-16,31-36,43-58,62-65,72]. The special thermoresponsive property of gelatin allows the hydrogels to be printed layer by layer in a controlled manner. All cell types can be encapsulated in the gelatin based sol-gel hydrogels for complex organ construction. Branched vascular systems can be obtained with a synthetic polymer overcoat for anti suture purpose [22-24,56,57]. Nevertheless, the gel states of the gelatin-based hydrogels are not stable when the environmental temperature is over $20^{\circ} \mathrm{C}$ or the printed constructs are put into a culture medium. Consequently, the cell-laden hydrogels need to be crosslinked to yield a defined shape or a stable 3D structure after printing [18,43-59].

Evidently, the number of biomaterials that can be simultaneously printed depends mainly on the nozzle numbers of an extrusion-based bioprinter. Different material systems can be integrated into a construct by choosing proper printing parameters. For example, in our group, we have developed various multinozzle bioprinters for different organ manufacturing. Especially, two robotic arm controlled injectable nozzles and two extrusion-based syringes have been combined for solid organs, such as the breast, liver and heart, manufacturing [91]. We have assembled various cells, such as ADSCs and hepatocytes, using our homemade multiple nozzle cell 3D printers, to produce complex organ precursors with branching vascular systems inside, and to convert ADSCs into vascular endothelial cells and smooth muscle cells in the 3D constructs [22-24]. Figure 2 is an illustration of a two-syringe RP technique $[10,48]$. Figure 3 is an illustration of liver manufacturing with a four-nozzle bioprinter and multiple biomaterials. Four different biomaterials can be simultaneously printed together.Thereby, it can meet the requirements for stable vascular system formation within 
a hybrid hierarchical polyurethane-cell/hydrogel construct $[10,11]$. Correspondingly, it was the first time some new words, such as "inner scaffold" and "outer scaffold", have appeared in our manuscripts and cover letters. With the similar integrations of extrusion nozzles and biomaterials, Kang and coworkers have produced human scale bone, cartilage and muscle tissues with a composite gelatin/fibrinogen/hyaluronan/glycerol hydrogel [17]. The combination of different biodegradable polymers in one hydrogel has been proved to be an effective way in 3D bioprinting techniques, especially for complex organ manufacturing.

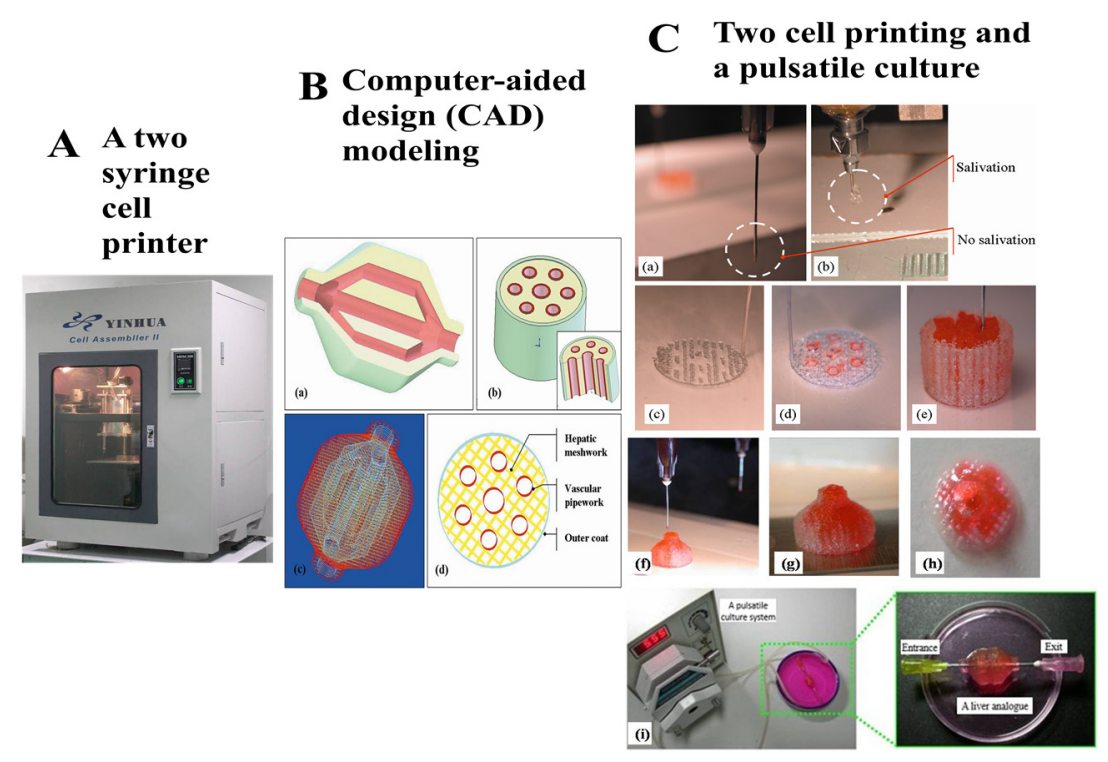

Figure 2. A two-nozzle 3D bioprinting technique developed in Tsinghua University Prof. Wang's group. Two different cell types in the gelatin-based hydrogels have been assembled simultaneously into a construct [10]. (A) The two-syringe/nozzle cell printing machine; (B) A computer-aided design model; (C) Adipose-derive stem cells and hepatocyte have been printed together with a branched vascular system and pulsatile cultured after printing.

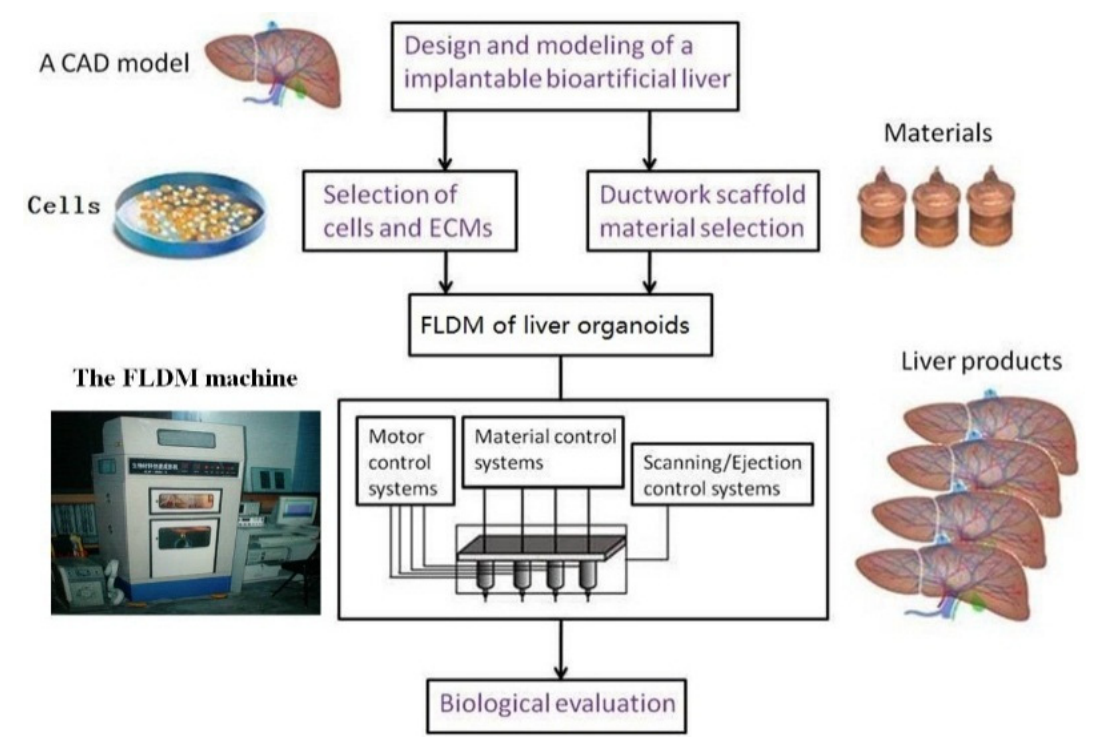

Figure 3. Schematic description of the modeling and manufacturing processes of liver lobes with a four-nozzle low-temperature deposition manufacturing (FLDM) system developed in Tsinghua University, Prof. Wang's group [10,11]. 


\section{Stem Cells in Bioprinting}

There is a current trend to combine stem cells and growth factors with ECMs in 3D milieus to mimic organ development [92-105]. In fact, with the proper use of growth factors, stem cells can be induced into multiple tissues with a cocktail growth factor engagement approach [22-24,52-58]. With this approach, stem cells are regarded as the ideal cell types for bioprinting.

Especially, embryonic stem cells (ESCs) have been used for developmental biology, regenerative medicine, cell replacement therapy and drug discovery with high differentiation potentialities [106]. However, in view of the moral issue, the applications of ESCs in 3D bioprinting techniques have been greatly influenced. Currently, some somatic stem cells, such as adipose-derived stem cells (ADSCs) and induced pluripotent stem cells (iPSCs), are becoming increasingly popular and attractive [107-112].

ADSCs are easily accessible from mammalian epithelial tissues in large quantities [113-118]. ADSCs can differentiate into cardiac cells/ muscles, endothelial cells/tissues, smooth cells/muscle, and be used in many bioapplications. In addition, ADSCs have extra lineage differentiations, including adipocytes, chondrocytes, hepatocytes, pancreatic cells, neuronal-like cells, osteoblasts, pancreas cell lines and bone-related cells [119-121]. As stated above, in our group, we have incorporated ADSCs in various natural biodegradable polymer hydrogels for complex organ manufacturing [9-16,48-58]. Extremely high cell viabilities can be achieved by optimizing the printing parameters. The printing processes have no adverse effects on the stem cell proliferation and differentiation abilities. Multiple tissues can be easily coordinated in the printed construct due to the growth factor incorporation before printing or cocktail growth factor engagement after printing [9-16,48-58]. Particularly, the location or spatial effects of growth factor engagement are prominent for the printed stem cells [6,22-24]. All the stem cells can be engaged to differentiate into target cell types in the constructs. Different vascular segments can be printed with different extrusion nozzles and biomaterials. It is therefore the most effective way for complex organ printing [6-16,22-24].

iPSC is a perfect cell type for its feature of overcoming the difficulty of the limitations associated with the current cell sources and has developed very quickly. iPSCs have the potential to differentiate into almost all kinds of cells for different tissues, such as nerve, blood, bone, and heart, under appropriate conditions. Currently, iPSC lines of rats [122], pigs [123], humans [124], monkeys [125] and rabbits [126] have been set up successfully. Some researchers have chosen to focus on iPSCs for disease model establishment, drug discovery template, energy metabolic research, cell therapy and organ manufacturing. In detail, the methods of generating integration-free iPSCs are as followings: non-integrating DNA methods, RNA-based methods, proteins-based methods [127-129]. Similar to other cell printing techniques, 3D stem cell printing can provide stem cells with complex 3D cellular microenvironments similar to their native counterparts. Patient self-derived stem cells can solve the immune rejection issues.

Thus far, the research about stem cells and regenerative medicine is increasingly piling up, which brings more opportunities and injects new vitalities to effectively treat end failure organs [6-16,18-58,98-106]. Consequently, the number of published papers and financial support from government have increased dramatically [130].

\section{Future Outlook}

Bioprinting technology has obtained growing popularity for its favorable meanings. Some groups have made great progress with the pertinent techniques in tissue engineering, organ manufacturing and drug screening areas. Biodegradable polymers are usually used as the cell printing ECMs or accommodations, while stem cell techniques are especially helpful in complex organ manufacturing. The development and future of bioprinting techniques are promising: (1) it can solve the donor shortage problems of organ transplantation; (2) it can overcome the immune rejection symptoms caused by allograft tissue/organ transplantation; (3) it can reduce the high cost and heavy burden of the patients with reverse engineering and personal manufacturing techniques; (4) it can establish 
a platform for high-throughput drug screening and organ manufacturing; and (5) it can be easily accepted by researchers and doctors with those CAD tissue/organ models.

Nevertheless, the development of bioprinting is still imperative and challenging. In particular, several aspects should be further addressed: (1) lack of design principles for bioprinting despite an emergency in additive manufacturing areas [131-133]; (2) further 4D, 5D even 6D development based on the 2D and 3D printing techniques [134,135]; (3) optimal stem cells induction approaches before, during or after the printing processes; (4) multiple cell type or biomaterial system incorporation protocols for complex tissue/organ manufacturing; (5) special cell culture incubators to acquire large amount of cells in a short time period; (6) biological functionality realization within the 3D printed substitutions; (7) harsh environment factor reduction (such as temperature and pressure) for biological property maintenance of the integrated cells and growth factors; and (8) typical zone or layer designs for complex organ products. Further multidisciplinary research and cooperation are still urgently needed relating to biology, chemistry, medicine, materials, mechanics, and pathophysiology sciences and technologies. More and more high-throughput manufacturing products, such as the liver, heart, kidney, skin, cartilage and bones, will become possible with promising 3D bioprinting technologies. We are herein expecting a bright and fruitful future for the modern multinozzle 3D bioprinting techniques.

Acknowledgments: The work was supported by grants from the Cross-Strait Tsinghua Cooperation Basic Research (No. 2012THZ02-3), Beijing Municipal Natural Science Foundation (No. 3152015), National Natural Science Foundation of China (NSFC) (No. 81571832, 81271665 and 30970748), International Cooperation and Exchanges NSFC and Japanese Society for the Promotion of Science (JSPS) (No. 81411140040) and the National High Tech 863 Grant (No. 2009AA043801).

Author Contributions: Meijuan Lei collected the data and completed the primary manuscript; Xiaohong Wang assigned, augmented, edited and improved the work.

Conflicts of Interest: The authors declare no conflict of interest.

\section{References}

1. Allemani, C.; Weir, H.K.; Carreira, H.; Harewood, R.; Spika, D.; Wang, X.-S.; Bannon, F.; Ahn, J.V.; Johnson, C.J.; Bonaventure, A.; et al. Global surveillance of cancer survival 1995-2009: Analysis of individual data for 25,676,887 patients from 279 population-based registries in 67 countries (CONCORD-2). Lancet 2015, 385, 977-1010. [CrossRef]

2. Dalal, A.R. Philosophy of organ donation: Review of ethical facets. World J. Transplant. 2015, 24, 44-51. [CrossRef]

3. Orive, G.; Hernández, R.M.; Gascón, A.R. History, challenges and perspectives of cell microencapsulation. Trends Biotechnol. 2004, 22, 87-92. [CrossRef] [PubMed]

4. Moniaux, N.; Faivre, J.A. Reengineered liver for transplantation. J. Hepatol. 2011, 54, 386-387. [CrossRef] [PubMed]

5. Wang, X. Overview on biocompatibilities of implantable biomaterials. In Advances in Biomaterials Science and Biomedical Applications in Biomedicine; Lazinica, R., Ed.; InTech: Rijeka, Croatia, 2013; pp. 111-155.

6. Wang, X. Spatial effects of stem cell engagement in 3D printing constructs. J. Stem Cells Res. Rev. Rep. 2014, 1, $5-9$.

7. Griffin, M.F.; Butler, P.E.; Seifalian, A.M.; Kalaskar, D.M. Control of stem cell fate by engineering their micro and nanoenvironment. World J. Stem Cells 2015, 7, 37-50. [CrossRef] [PubMed]

8. Wang, X.; Rijff, B.L.; Khang, G. A building block approach into 3D printing a multi-channel organ regenerative scaffold. J. Stem Cell Res. Ther. 2015. [CrossRef]

9. Schrepfer, I.; Wang, X. Progress in 3D printing technology in health care. In Organ Manufacturing; Wang, X., Ed.; Nova Science Publishers Inc.: Hauppauge, NY, USA, 2015; pp. 29-74.

10. Wang, X.; Tuomi, J.; Mäkitie, A.A.; Poloheimo, K.-S.; Partanen, J.; Yliperttula, M. The integrations of biomaterials and rapid prototyping techniques for intelligent manufacturing of complex organs. In Advances in Biomaterials Science and Applications in Biomedicine; Lazinica, R., Ed.; InTech: Rijeka, Croatia, 2013; pp. 437-463. 
11. Wang, X. Intelligent freeform manufacturing of complex organs. Artif. Org. 2012, 36, 951-961. [CrossRef] [PubMed]

12. Wang, X.; Zhang, Q. Overview on "Chinese-Finnish workshop on biomanufacturing and evaluation techniques". Artif. Org. 2011, 35, E191-E193. [CrossRef] [PubMed]

13. Liu, L.; Wang, X. Organ manufacturing. In Organ Manufacturing; Wang, X.H., Ed.; Nova Science Publishers Inc.: Hauppauge, NY, USA, 2015; pp. 1-28.

14. Liu, L.; Wang, X. Creation of a vascular system for organ manufacturing. Int. J. Bioprint. 2015, 1, 77-86.

15. Wang, X.; Yan, Y.; Zhang, R. Recent trends and challenges in complex organ manufacturing. Tissue Eng. Part B 2010, 16, 189-197. [CrossRef] [PubMed]

16. Wang, X.; Yan, Y.; Zhang, R. Rapid prototyping as tool for manufacturing bioartificial livers. Trends Biotechnol. 2007, 25, 505-513. [CrossRef] [PubMed]

17. Kang, H.-W.; Lee, S.J.; Ko, I.K.; Kengla, C.; Yoo, J.J.; Atala, A. A 3D bioprinting system to produce human-scale tissue constructs with structural integrity. Nat. Biotechnol. 2016. [CrossRef] [PubMed]

18. Wang, X.; Yan, Y.; Zhang, R. Gelatin-based hydrogels for controlled cell assembly. In Biomedical Applications of Hydrogels Handbook; Ottenbrite, R.M., Ed.; Springer: New York, NY, USA, 2010; pp. 269-284.

19. $\mathrm{Xu}, \mathrm{Y}$.; Wang, $\mathrm{X}$. Application of 3D biomimetic models for drug delivery and regenerative medicine. Curr. Pharm. Des. 2015, 21, 1618-1626. [CrossRef] [PubMed]

20. Liu, L.; Zhou, X.; Xu, Y.; Zhang, W.M.; Liu, C.-H.; Wang, X.H. Controlled release of growth factors for regenerative medicine. Curr. Pharm. Des. 2015, 21, 1627-1632. [CrossRef] [PubMed]

21. Wang, X. Editorial: Drug delivery design for regenerative medicine. Curr. Pharm. Des. 2015, 21, $1503-1505$. [CrossRef] [PubMed]

22. Wang, X.; Huang, Y.; Liu, C. A combined rotational mold for manufacturing a functional liver system. J. Bioact. Compat. Polym. 2015, 39, 436-451. [CrossRef]

23. Wang, X.; Wang, J. Vascularization and adipogenesis of a spindle hierarchical adipose-derived stem cell/collagen/alginate-PLGA construct for breast manufacturing. Int. J. Innov. Technol. Explor. Eng. 2015, 4, 1-8.

24. Zhao, X.; Liu, L.; Wang, J.; Xu, Y.F.; Zhang, W.M.; Khang, G.; Wang, X.H. In vitro vascularization of a combined system based on a 3D bioprinting technique. J. Stem Cell Res. Ther. 2014. [CrossRef]

25. Murphy, S.V.; Atala, A. 3D bioprinting of tissues and organs. Nat. Biotechnol. 2014, 32, 773-785. [CrossRef] [PubMed]

26. Boland, T.; Xu, T.; Damon, B.; Cui, X. Application of inkjet printing to tissue engineering. Biotechnol. J. 2006, 1,910-917. [CrossRef] [PubMed]

27. Singh, M.; Haverinen, H.M.; Dhagat, P.; Jabbour, G.E. Inkjet printing_Process and its applications. Adv. Mater. 2010, 22, 673-685. [CrossRef] [PubMed]

28. Derby, B. Printing and prototyping of tissues and scaffolds. Science 2012, 338, 921-926. [CrossRef] [PubMed]

29. Guillotin, B.; Souquet, A.; Catros, S.; Duocastella, M.; Pippenger, B.; Bellance, S.V. Laser assisted bioprinting of engineered tissue with high cell density and microscale organization. Biomaterials 2010, 31, 7250-7256. [CrossRef] [PubMed]

30. Ozbolat, I.T.; Chen, H.; Yu, Y. Development of "Multi-arm Bioprinter" for hybricd biofabrication of tissue engineering constructs. Biomaterials 2014, 30, 259-304.

31. Tasoglu, S.; Demirci, U. Bioprinting for stem cell research. Trends Biotechnol. 2013, 31, 10-19. [CrossRef] [PubMed]

32. Seol, Y.J.; Kang, H.W.; Lee, S.J.; Atala, A.; Yoo, J.J. Bioprinting technology and its applications. Eur. J. Cardiothorac Surg. 2014, 46, 342-348. [CrossRef] [PubMed]

33. Wang, M.; He, J.; Liu, Y.; Li, M.; Li, D.; Jin, Z. The trend towards in vivo bioprinting. Int. J. Bioprint. 2015, 1, 15-26.

34. Wang, X.; He, K.; Zhang, W. Optimizing the fabrication processes for manufacturing a hybrid hierarchical polyurethane-cell/hydrogel construct. J. Bioact. Compat. Polym. 2013, 28, 303-319. [CrossRef]

35. Huang, Y.; He, K.; Wang, X. Rapid Prototyping of a hybrid hierarchical polyurethane-cell/hydrogel onstruct for regenerative medicine. Mater. Sci. Eng. C 2013, 33, 3220-3229. [CrossRef] [PubMed]

36. Ozbolat, I.T.; Yin, Y. Bioprinting Toward Organ Fabrication: Challenges and Future Trends. IEEE Trans. Biomed. Eng. 2013, 60, 691-699. [CrossRef] [PubMed] 
37. Hopp, B.; Smausz TKresz, N.; Barna, N.; Bor, Z.; Kolozsvari, L.; Chrisey, D.B.; Szabo, A.; Nogradi, A. Survival and proliferative ability of various living cell types after laser-induced forward transfer. Tissue Eng. 2005, 11, 1817-1823. [CrossRef] [PubMed]

38. Gruene, M.; Deiwick, A.; Koch, L.; Schlie, S.; Unger, C.; Hofmann, N.; Bernemann, I.; Glasmacher, B.; Chichkov, B. Laser printing of stem cells for biofabrication of scaffold-free autologous grafts. Tissue Eng. Part C Methods 2011, 17, 79-87. [CrossRef] [PubMed]

39. Guillemot, F.; Souquet, A.; Catros, S.; Guillotin, B.; Lopez, J.; Faucon, M.; Pippenger, B.; Bareille, R.; Rémy, M.; Bellance, S.; et al. High-throughput laser printing of cells and biomaterials for tissue engineering. Acta Biomater. 2010, 6, 2494-2500. [CrossRef] [PubMed]

40. Odde, D.J.; Renn, M.J. Laser-guided direct writing for applications in biotechnology. Trends Biotechnol. 1999, 17, 385-389. [CrossRef]

41. Cui, X.; Boland, T. Human microvasculature fabrication using thermal inkjet printing technology. Biomaterials 2009, 30, 6221-6227. [CrossRef] [PubMed]

42. Duan, B.; Hockaday, L.A.; Kang, K.H.; Butcher, J.T. 3D Bioprinting of heterogeneous aortic valve conduits with alginate/gelatin hydrogels. J. Biomed. Mater. Res. A 2013, 101, 1255-1264. [CrossRef] [PubMed]

43. Yan, Y.; Wang, X.; Pan, Y.; Liu, H.; Cheng, J.; Xiong, Z.; Lin, F.; Wu, R.; Zhang, R.; Lu, Q. Fabrication of viable tissue-engineered constructs with 3D cell-assembly technique. Biomaterials 2005, 26, 5864-5871. [CrossRef] [PubMed]

44. Wang, X.; Yan, Y.; Pan, Y.; Xiong, Z.; Liu, H.; Cheng, J.; Liu, F.; Lin, F.; Wu, R.; Zhang, R.; et al. Generation of three-dimensional hepatocyte/gelatin structures with rapid prototyping system. Tissue Eng. 2006, 12, 83-90. [CrossRef] [PubMed]

45. Xu, W.; Wang, X.; Yan, Y.; Zheng, W.; Xiong, Z.; Lin, F.; Wu, R.; Zhang, R. Rapid prototyping three-dimensional cell/gelatin/fibrinogen constructs for medical regeneration. J. Bioact. Compat. Polym. 2007, 22, 363-377. [CrossRef]

46. Zhang, T.; Yan, Y.; Wang, X.; Xiong, Z.; Lin, F.; Wu, R.; Zhang, R. Three-dimensional gelatin and gelatin/hyaluronan hydrogel structures for traumatic brain injury. J. Bioact. Compat. Polym. 2007, 22, 19-29. [CrossRef]

47. Xu, W.; Wang, X.; Yan, Y.; Zhang, R. Rapid prototyping of polyurethane for the creation of vascular systems. J. Bioact. Compat. Polym. 2008, 23, 103-114. [CrossRef]

48. Li, S.; Xiong, Z.; Wang, X.; Yan, Y.; Liu, H.; Zhang, R. Direct fabrication of a hybrid cell/hydrogel construct by a double-nozzle assembling technology. J. Bioact. Compat. Polym. 2009, 24, 249-265.

49. Li, S.; Yan, Y.; Xiong, Z.; Weng, C.; Zhang, R.; Wang, X. Gradient hydrogel construct based on an improved cell assembling system. J. Bioact. Compat. Polym. 2009, 24, 84-99.

50. Sui, S.; Wang, X.; Liu, P.; Yan, Y.; Zhang, R. Cryopreservation of cells in 3D constructs based on controlled cell assembly processes. J. Bioact. Compat. Polym. 2009, 24, 473-487. [CrossRef]

51. Wang, X.; Xu, H. Incorporation of DMSO and dextran-40 into a gelatin/alginate hydrogel for controlled assembled cell cryopreservation. Cryobiology 2010, 61, 345-351. [CrossRef] [PubMed]

52. Yao, R.; Zhang, R.; Yan, Y.; Wang, X. In vitro angiogenesis of 3D tissue engineered adipose tissue. J. Bioact. Compat. Polym. 2009, 24, 5-24.

53. Yao, R.; Zhang, R.; Wang, X. Design and evaluation of a cell microencapsulating device for cell assembly technology. J. Bioact. Compat. Polym. 2009, 24, 48-62.

54. Xu, M.; Wang, X.; Yan, Y.; Yao, R.; Ge, Y. A cell-assembly derived physiological 3D model of the metabolic syndrome, based on adipose-derived stromal cells and a gelatin/alginate/fibrinogen matrix. Biomaterials 2010, 31, 3868-3877. [CrossRef] [PubMed]

55. Xu, M.; Yan, Y.; Liu, H.; Yao, Y.; Wang, X. Control adipose-derived stromal cells differentiation into adipose and endothelial cells in a 3-D structure established by cell-assembly technique. J. Bioact. Compat. Polym. 2009, 24, 31-47. [CrossRef]

56. Wang, X.; Sui, S.; Yan, Y.; Zhang, R. Design and fabrication of PLGA sandwiched cell/fibrin constructs for complex organ regeneration. J. Bioact. Compat. Polym. 2010, 25, 229-240. [CrossRef]

57. Zhao, X.; Wang, X. Preparation of an adipose-derived stem cell (ADSC)/ fibrin-PLGA construct based on a rapid prototyping technique. J. Bioact. Compat. Polym. 2013, 28, 191-203. [CrossRef]

58. Xu, Y.; Wang, X. Fluid and cell behaviors along a 3D printed alginate/gelatin/fibrin channel. Bioeng. Biotech. 2015, 112, 1683-1695. [CrossRef] [PubMed] 
59. Nair, L.S.; Laurencin, C.T. Biodegradable polymers as biomaterials. Prog. Polym. Sci. 2007, 32, $762-798$. [CrossRef]

60. Lee, Y.B.; Polio, S.; Lee, W.; Dai, G.; Menon, L.; Carroll, R.S.; Yoo, S.S. Bio-printing of collagen and VEGF-releasing fibrin gel scaffolds for neural stem cell culture. Exp. Neurol. 2010, 223, 645-652. [CrossRef] [PubMed]

61. Wang, S.; Lee, J.M.; Yeong, W.Y. Smart hydrogels for bioprinting. Int. J. Bioprint. 2015, 1, 3-14. [CrossRef]

62. Roth, E.A.; Xu, T.; Das, M.; Gregory, C.; Hichman, J.J.; Boland, T. Inkjet printing for high-throughput cell patterning. Biomaterials 2004, 25, 3707-3715. [CrossRef] [PubMed]

63. Lloyd, A.W. Interfacial bioengineering to enhance surface biocompatibility. Med. Device Technol. 2002, 13, 18-21. [PubMed]

64. Vasir, B.; Reitz, P.; Xu, G.; Sharma, A.; Bonner, W.S.; Weir, G.C. Effects of diabetes and hypoxia on gene markers of angiogenesis (HGF, cMET, uPA and uPAR, TGF- $\alpha$, TGF- $\beta$, bFGF and Vimentin) in cultured and transplanted rat islets. Diabetologia 2000, 43, 763-768. [CrossRef] [PubMed]

65. Moreira Teixeira, L.S.; Bijl, S.; Pully, V.V.; Otto, C.; Jin, R.; Feijen, J.; van Blitterswijk, C.A.; Dijkstra, P.J.; Karperien, M. Self-attaching and cell-attracting in-situ forming dextran-tyramine conjugates hydrogels for arthroscopic cartilage repair. Biomaterials 2012, 33, 3164-3174. [CrossRef] [PubMed]

66. Billiet, T.; Vandenhaute, M.; Schelfhout, J.; van Vlierberghe, S.; Dubruel, P. A review of trends and limitations in hydrogel-rapid prototyping for tissue engineering. Biomaterials 2012, 33, 6020-6041. [CrossRef] [PubMed]

67. Shim, J.-H.; Lee, J.-S.; Kim, J.Y.; Cho, D.W. Bioprinting of a mechanically enhanced three-dimensional dual cell-laden construct for osteochondral tissue engineering using a multi-head tissue/organ building system. J. Micromech. Microeng. 2012, 22. [CrossRef]

68. Li, C.; Faulkner-Jones, A.; Dun, A.R.; Jin, J.; Chen, P.; Xing, Y.; Yang, Z.; Li, Z.; Shu, W.; Liu, D.; et al. Rapid formation of a supramolecular polypeptide-DNA hydrogel for in situ three-dimensional multilayer bioprinting. Angew. Chem. Int. Ed. 2015, 54, 3957-3961. [CrossRef] [PubMed]

69. Buell, A.K.; Blundel, J.R.; Dobson, C.M.; Welland, M.E.; Terentjev, E.M.; Knowles, T.P. Frequency factors in a landscape model of filamentous protein aggregation. Phys. Rev. Lett. 2010, 104. [CrossRef] [PubMed]

70. Nielsen, T.K.; Manickam, K.; Hirscher, M.; Besenbacher, F.; Jensen, T.R. Confinement of MgH2 nanoclusters within nanoporous aerogel scaffold materials. ACS Nano. 2009, 3, 3521-3528. [CrossRef] [PubMed]

71. Ahmed, E.M. Hydrogel: Preparation, characterization, and applications: A review. J. Adv. Res. 2015, 6, 105-121. [CrossRef] [PubMed]

72. Golden, A.P.; Tien, J. Fabrication of microfluidic hydrogels using molded gelatin as a sacrificial element. Lab Chip 2007, 7, 720-725. [CrossRef] [PubMed]

73. Lee, C.H.; Singla, A.; Lee, Y. Biomedical applications of collagen. Int. J. Pharm. 2001, 221. [CrossRef]

74. Vert, M. Aliphatic polyesters: Great degradable polymers that cannot do everything. Biomacromolecules 2005, 6, 538-546. [CrossRef] [PubMed]

75. Park, J.B.; Lakes, R.S. Biomaterials: An Introduction, 2nd ed.; Plenum Press: New York, NY, USA, 1992.

76. Alberts, B.; Bray, D.; Lewis, J.; Raff, M.; Roberts, K.; Watson, J.D. Molecular Biology of the Cell, 3rd ed.; Garland Publishing, Inc.: New York, NY, USA, 1994.

77. Drury, J.L.; Mooney, D.J. Hydrogels for tissue engineering: Scaffold design variables and applications. Biomaterials 2003, 24, 4337-4351. [CrossRef]

78. Best, S.M.; Porter, A.E.; Thian, E.S.; Huang, J. Bioceramics: Past, presentand for the future. J. Eur. Ceram. Soc. 2008, 28, 1319-1327. [CrossRef]

79. Pati, F.; Jang, J.; Ha, D.-H.; Kim, D.H.; Cho, D.W. Printing three-dimensional tissue analogues with decellularized extracellular matrix bioink. Nat. Commun. 2014, 5. [CrossRef] [PubMed]

80. Liang, Y.; Liu, W.; Han, B.; Yang, C.; Ma, Q.; Song, F.; Bi, Q. An in situ formed biodegradable hydrogel for reconstruction of the corneal endothelium. Coll. Surf. B Biointerfaces 2011, 82. [CrossRef] [PubMed]

81. Boccaccini, A.R.; Blaker, J.J. Bioactive composite materials for tissue engineering scaffolds. Expert. Rev. Med. Devices 2005, 2, 303-317. [CrossRef] [PubMed]

82. Puppi, D.; Chiellini, F.; Piras, A.M.; Chiellini, E. Polymeric materials for bone and cartilage repair. Prog. Polym. Sci. 2012, 35, 403-440. [CrossRef]

83. Bryant, S.J.; Anseth, K.S. The effects of scaffold thickness on tissue engineered cartilage in photocrosslinked poly(ethylene oxide) hydrogels. Biomaterials 2001, 22, 619-626. [CrossRef] 
84. Peppas, N.A.; Khare, A.R. Preparation, structure and diffusional behavior of hydrogels in controlled release. Adv. Drug Deliv. Rev. 1993, 11. [CrossRef]

85. Wang, X.; Paloheimo, K.-S.; Xu, H.; Liu, C. Cryopreservation of cell/hydrogel constructs based on a new cell-assembling technique. J. Bioact. Compat. Polym. 2010, 25, 634-653. [CrossRef]

86. Tan, Y.S.E.; Yeong, W.Y. Direct bioprinting of alginate-based tubular constructs using multi-nozzle extrusion-based technique. In Proceedings of the 1st International Conference on Progress in Additive Manufacturing, Nanyang, Singapore, 26-28 May 2014. [CrossRef]

87. Song, S.-J.; Choi, J.; Park, Y.-D.; Hong, S.; Lee, J.J.; Ahn, C.B.; Choi, H.; Sun, K. Sodium alginate hydrogel-based bioprinting using a novel multinozzle bioprinting system. Artif. Org. 2011, 35, 1132-1136. [CrossRef] [PubMed]

88. Rouillard, A.D.; Berglund, C.M.; Lee, J.Y.; Polacheck, W.J.; Tsui, Y.; Bonassar, L.J.; Kirby, B.J. Methods for photocrosslinking alginate hydrogel scaffolds with high cell viability. Tissue Eng. Part C Methods 2011, 17, 173-179. [CrossRef] [PubMed]

89. Ganesh, N.; Hanna, C.; Nair, S.V.; Nair, L.S. Enzymatically cross-linked alginic-hyaluronic acid composite hydrogels as cell delivery vehicles. Int. J. Biol. Macromol. 2013, 55, 289-294. [CrossRef] [PubMed]

90. Yu, J.; Du, K.T.; Fang, Q.; Gu, Y.; Mihardja, S.S.; Sievers, R.E.; Wu, J.C.; Lee, R.J. The use of human mesenchymal stem cells encapsulated in RGD modified alginate microspheres in the repair of myocardial infarction in the rat. Biomaterials 2010, 31, 7012-7020. [CrossRef] [PubMed]

91. Wang, J.; Wang, X. Development of a Combined 3D Printer and Its Application in Complex Tissue Construction. Master's Thesis, Tsinghua University, Beijing, China, 2014.

92. Liu, L.; Wang, X. Artificial blood vessels and vascular systems. In Organ Manufacturing; Wang, X., Ed.; Nova Science Publishers Inc.: Hauppauge, NY, USA, 2015; pp. 75-99.

93. Xu, Y.; Li, D.; Wang, X. Current trends and challenges for producing artificial hearts. In Organ Manufacturing; Wang, X., Ed.; Nova Science Publishers Inc.: Hauppauge, NY, USA, 2015; pp. 101-125.

94. Zhou, X.; Wang, X. Artificial lung manufacturing. In Organ Manufacturing; Wang, X., Ed.; Nova Science Publishers Inc.: Hauppauge, NY, USA, 2015; pp. 127-151.

95. Lei, M.; Wang, X. Rapid prototyping of artificial stomachs. In Organ Manufacturing; Wang, X., Ed.; Nova Science Publishers Inc.: Hauppauge, NY, USA, 2015; pp. 153-169.

96. Henzler, T.; Chai, L.; Wang, X. Integrated model for organ manufacturing: A systematic approach from medical imaging to rapid prototyping. In Organ Manufacturing; Wang, X., Ed.; Nova Science Publishers Inc.: Hauppauge, NY, USA, 2015; pp. 171-200.

97. Xu, Y.; Li, D.; Wang, X. Liver manufacturing approaches: The thresholds of cell manipulation with bio-friendly materials for multifunctional organ regeneration. In Organ Manufacturing; Wang, X., Ed.; Nova Science Publishers Inc.: Hauppauge, NY, USA, 2015; pp. 201-225.

98. Zhou, X.; Wang, X. Artificial Kidney Manufacturing. In Organ Manufacturing; Wang, X., Ed.; Nova Science Publishers Inc.: Hauppauge, NY, USA, 2015; pp. 227-244.

99. Xu, Y.; Li, D.; Wang, X. The construction of vascularized pancreas based on 3D printing techniques. In Organ Manufacturing; Wang, X., Ed.; Nova Science Publishers Inc.: Hauppauge, NY, USA, 2015; pp. 245-268.

100. Leonard, J.F.; Chai, L.; Wang, X. Application of gelatin and glucose as sacrificial structures in organ manufacturing. In Organ Manufacturing; Wang, X., Ed.; Nova Science Publishers Inc.: Hauppauge, NY, USA, 2015; pp. 269-300.

101. Liu, L.; Wang, X. Hared tissue and organ manufacturing. In Organ Manufacturing; Wang, X., Ed.; Nova Science Publishers Inc.: Hauppauge, NY, USA, 2015; pp. 301-333.

102. Lei, M.; Wang, X. Uterus Bioprinting. In Organ Manufacturing; Wang, X., Ed.; Nova Science Publishers Inc.: Hauppauge, NY, USA, 2015; pp. 335-355.

103. Zhou, X.; Wang, X. Breast Engineering. In Organ Manufacturing; Wang, X., Ed.; Nova Science Publishers Inc.: Hauppauge, NY, USA, 2015; pp. 357-384.

104. Zhou, X.; Wang, X. Skin Substitute Manufacturing. In Organ Manufacturing; Wang, X., Ed.; Nova Science Publishers Inc.: Hauppauge, NY, USA, 2015; pp. 385-408.

105. Zimmermann, S.; Chai, L.; Wang, X. Progress of electrospinning in organ manufacturing. In Organ Manufacturing; Wang, X., Ed.; Nova Science Publishers Inc.: Hauppauge, NY, USA, 2015; pp. 409-451.

106. Keller, G. Embryonic stem cell differentiation: Emergence of a new era in biology and medicine. Gene Dev. 2015, 29, 1129-1155. [CrossRef] [PubMed] 
107. Zhao, X.; Du, S.; Chai, L.; Xu, Y.; Liu, L.; Zhou, X.; Wang, J.; Zhang, W.; Liu, C.-H.; Wang, X. Anti-cancer drug screening based on an adipose-derived stem cell/hepatocyte 3D printing technique. J. Stem Cell Res. Ther. 2015, 5. [CrossRef]

108. Zhou, X.; Zhou, X.; Liu, C.; Wang, X.H. A 3D bioprinting liver tumor model for drug screening. World J. Pharm. Pharm. Sci. 2016. [CrossRef]

109. Wang, X. 3D printing of tissue/organ scaffolds for regenerative medicine. In Handbook of Intelligent Scaffolds for Regenerative Medicine, 2nd ed.; Pan Stanford Publishing: Palo Alto, CA, USA, 2016; in press.

110. Mehrban, N.; Teoh, G.Z.; Birchall, M.A. 3D bioprinting for tissue engineering: Stem cells in hydrogels. Int. J. Bioprint. 2016, 1. [CrossRef]

111. He, K.; Wang, X. Rapid prototyping of tubular polyurethane and cell/hydrogel constructs. J. Bioact. Compat. Polym. 2011, 26, 363-374.

112. Wang, X.; Sui, S. Pulsatile culture of a poly(DL-lactic-co-glycolic acid) sandwiched cell/hydrogel construct fabricated using a step-by-step mold/extraction method. Artif. Organs 2011, 35, 645-655. [CrossRef] [PubMed]

113. Jeffrey, M.G.; Adam, J.K.; Bruce, A.B. Adipose-derived stem cells for regenerative medicine. Circ. Res. 2007, $100,1249-1260$.

114. Planat, B.V.; Menard, C.; André, M.; Puceat, M.; Perez, A.; Garcia, V.J.M.; Pénicaud, L.; Casteilla, L. Spontaneous cardiomyocyte differentiation from adipose tissue stroma cells. Circ. Res. 2004, 94, 223-229. [CrossRef] [PubMed]

115. Stuart, K.W.; Wang, T.F.; Robert, C.; Bruce, E.J. Liposuction-derived human fat used for vascular graft sodding contains endothelial cells and not mesothelial cells as the major cell type. J. Vasc. Surg. 1994, 19, 916-923.

116. Jeon, E.S.; Moon, H.J.; Lee, M.J.; Song, H.Y.; Kim, Y.M.; Bae, Y.C.; Jung, J.S.; Kim, J.H. Sphingosylphosphorylcholine induces differentiation of human mesenchymal stem cells into smoothmuscle-like cells through a TGF-beta-dependent mechanism. J. Cell Sci. 2006, 119, 4994-5005. [CrossRef] [PubMed]

117. Lee, W.C.; Rubin, J.P.; Marra, K.G. Regulation of alpha-smooth muscle actinprotein expression in adipose-derived stem cells. Cells Tissues Organs 2006, 183, 80-86. [CrossRef] [PubMed]

118. Kingham, P.J.; Kalbermatten, D.F.; Mahay, D.; Armstrong, S.J.; Wiberg, M.; Terenghi, G. Adipose-derived stem cells differentiate into a Schwann cell phenotype and promote neurite outgrowth in vitro. Exp. Neurol. 2007, 207, 267-274. [CrossRef] [PubMed]

119. Talens-Visconti, R.; Bonora, A.; Jover, R.; Mirabet, V.; Carbonell, F.; Castell, J.V.; Gómez-Lechón, M.J. Human mesenchymal stem cells from adipose tissue: Differentiation into hepatic lineage. Toxicol. In Vitro 2007, 21, 324-329. [CrossRef] [PubMed]

120. Nakagami, H.; Morishita, R.; Maeda, K.; Kikuchi, Y.; Ogihara, T.; Kaneda, Y. Adipose tissue-derived stromal cells as a novel option for regenerative cell therapy. J. Atheroscler. Thromb. 2006, 13, 77-81. [CrossRef] [PubMed]

121. Li, W.; Wei, W.; Zhu, S.; Zhu, J.; Shi, Y.; Lin, T.; Hao, E.; Hayek, A.; Deng, H.; Ding, S. Generation of rat and human induced pluripotent stem cells by combining genetic reprogramming and chemical inhibitors. Cell Stem Cell 2009, 4, 11-15. [CrossRef] [PubMed]

122. Wu, Z.; Chen, J.; Ren, J.; Bao, L.; Liao, J.; Cui, C.; Rao, L.; Li, H.; Gu, Y.; Dai, H.; et al. Generation of pig induced pluripotent stem cells with a drug-inducible system. J. Mol. Cell Biol. 2009, 1, 46-54. [CrossRef] [PubMed]

123. Yu, J.; Vodyanik, M.A.; Smuga-Otto, K.; Antosiewicz-Bourget, J.; Frane, J.L.; Tian, S.; Nie, J.; Jonsdottir, G.A.; Ruotti, V.; Stewart, R.; et al. Induced pluripotent stem cell lines derived from human somatic cells. Science 2007, 318, 1917-1920. [CrossRef] [PubMed]

124. Liu, H.; Zhu, F.; Yong, J.; Zhang, P.; Hou, P.; Li, H.; Jiang, W.; Cai, J.; Liu, M.; Cui, K.; et al. Generation of induced pluripotent stem cells from adult rhesus monkey fibroblasts. Cell Stem Cell 2008, 3, 587-590. [CrossRef] [PubMed]

125. Honda, A.; Hirose, M.; Hatori, M.; Matoba, S.; Miyoshi, H.; Inoue, K.; Ogura, A. Generation of induced pluripotent stem cells in rabbits: Potential experimental models for human regenerative medicine. J. Biol. Chem. 2010, 285, 31362-31369. [CrossRef] [PubMed] 
126. Stadtfeld, M.; Nagaya, M.; Utikal, J.; Weir, G.; Hochedlinger, K. Induced pluripotent stem cells generated without viral integration. Science 2008, 32, 945-949. [CrossRef] [PubMed]

127. Fusaki, N.; Ban, H.; Nishiyama, A.; Saeki, K.; Hasegawa, M. Efficient induction of transgene-free human pluripotent stem cells using a vectorbased on Sendai virus, an RNA virus that does not integrate into the host genome. Proc. Jpn. Acad. Phys. Biol. Sci. 2009, 85, 348-362. [CrossRef]

128. Kim, D.; Kim, C.-H.; Moon, J.-I.; Chang, M.-Y.; Han, B.-S.; Ko, S.; Yang, E.; Cha, K.Y.; Lanza, R.; Kim, K.-S. Generation of human induced pluripotent stem cells by direct delivery of reprogramming proteins. Cell Stem Cell 2009, 4, 472-476. [CrossRef] [PubMed]

129. Fu, X. Regenerative medicine research in China: From basic research to clinical practice. Sci. China Life Sci. 2014, 57, 155-156. [CrossRef] [PubMed]

130. Rosen, D.W. Computer-aided design for additive manufacturing of cellular structures. Comput. Aided Des. Appl. 2007, 4, 585-594. [CrossRef]

131. Rosen, D.W. Research supporting principles for design for additive manufacturing. Virtual Phys. Prototyp. 2014, 9, 225-232. [CrossRef]

132. Petrovic, V.; Haro, J.V.; Blasco, J.R.; Portolés, L. Additive manufacturing solutions for improved medical implants. In Biomedicine; Chao, L., Ed.; InTech: Rijeka, Croatia, 2012; pp. 7-180.

133. Khoo, Z.X.; Teoh, J.E.M.; Liu, Y.; Chua, C.K.; Yang, S.; An, J. 3D printing of smart materials: A review on recent progresses in 4D printing. Virtual Phys. Prototyp. 2015, 10, 103-122. [CrossRef]

134. An, J.; Chua, K.C.; Mironov, V. A perspective on 4D bioprinting. Int. J. Bioprint. 2016, 2, 3-5. [CrossRef]

135. Hanauer, N.; Latreille, P.L.; Alsharif, S.; Banquy, X. 2D, 3D and 4D active compound delivery in tissue engineering and regenerative medicine. Curr. Pharm. Des. 2015, 21, 1506-1516. [CrossRef] [PubMed]

(C) 2016 by the authors; licensee MDPI, Basel, Switzerland. This article is an open access article distributed under the terms and conditions of the Creative Commons Attribution (CC-BY) license (http://creativecommons.org/licenses/by/4.0/). 